University of Nebraska - Lincoln

DigitalCommons@University of Nebraska - Lincoln

\title{
Characterization of sorghum grain and evaluation of sorghum flour in a Chinese egg noodle system
}

\author{
Liman Liu \\ Kansas State University \\ Thomas J. Herald \\ USDA-ARS, tom.herald@ars.usda.gov \\ Donghai Wang \\ Kansas State University \\ Jeff D. Wilson \\ USDA-ARS \\ Scott R. Bean \\ USDA-ARS
}

See next page for additional authors

Follow this and additional works at: https://digitalcommons.unl.edu/usdaarsfacpub

Part of the Agricultural Science Commons

Liu, Liman; Herald, Thomas J.; Wang, Donghai; Wilson, Jeff D.; Bean, Scott R.; and Aramouni, Fadi M., "Characterization of sorghum grain and evaluation of sorghum flour in a Chinese egg noodle system" (2012). Publications from USDA-ARS / UNL Faculty. 858.

https://digitalcommons.unl.edu/usdaarsfacpub/858

This Article is brought to you for free and open access by the U.S. Department of Agriculture: Agricultural Research Service, Lincoln, Nebraska at DigitalCommons@University of Nebraska - Lincoln. It has been accepted for inclusion in Publications from USDA-ARS / UNL Faculty by an authorized administrator of DigitalCommons@University of Nebraska - Lincoln. 


\section{Authors}

Liman Liu, Thomas J. Herald, Donghai Wang, Jeff D. Wilson, Scott R. Bean, and Fadi M. Aramouni 


\title{
Characterization of sorghum grain and evaluation of sorghum flour in a Chinese egg noodle system
}

\author{
Liman Liu $^{a}$, Thomas J. Herald ${ }^{\mathrm{b}, *}$, Donghai Wang ${ }^{\mathrm{a}}$, Jeff D. Wilson ${ }^{\mathrm{b}}$, Scott R. Bean ${ }^{\mathrm{b}}$, Fadi M. Aramouni ${ }^{\mathrm{c}}$ \\ ${ }^{a}$ Department of Biological and Agricultural Engineering, Kansas State University, Manhattan, KS 66506, USA \\ ${ }^{\mathrm{b}}$ USDA-ARS, Center for Grain and Animal Health Research, Manhattan, 1515 College Ave., KS 66502, USA ${ }^{1}$ \\ ${ }^{\mathrm{c}}$ Food Science Institute, Kansas State University, Manhattan, KS 66506, USA
}

\section{A R T I C L E I N F O}

\section{Article history:}

Received 23 February 2011

Received in revised form

20 September 2011

Accepted 20 September 2011

\section{Keywords:}

Gluten-free

Sorghum

Grain characterization

Noodle texture and cooking qualities

\begin{abstract}
A B S T R A C T
Sorghum is a gluten free grain that has potential to be used as an alternative to wheat flour for the Celiac Sprue market. There are thousands of sorghum lines that have not been characterized for grain, flour or end product quality. The objective of the research was to gain an understanding among grain sorghum quality factors and Chinese egg noodles quality. Four sorghum hybrids were characterized and evaluated for kernel characteristics, proximate analysis, flour composition and end product in a Chinese egg noodle system. Kernel size and weight affected the flour particle size and the amount of starch damage. Flour with fine particle size and high starch damage conferred noodles with high firmness and high tensile strength. Water uptake was highest for flour with smaller particle size ( $38 \mu \mathrm{m}$ at $50 \%$ volume) and higher starch damage (6.14\%). Cooking losses for all samples were below $10 \%$. Starch of particle size $<5 \mu \mathrm{m}$ (Ctype) contributed to firmer and higher tensile strength noodles. Water absorption was significantly affected by flour particle size, starch particle size and starch damage. Through control of sorghum grain and flour quality characteristics it is possible to manufacture a Chinese egg noodle with good physical attributes.
\end{abstract}

() 2011 Elsevier Ltd. All rights reserved.

\section{Introduction}

The recent increase in the wheat free food market has been due to an increased awareness and diagnosis of celiac disease (Cole and Kagnoff, 1985; Collin et al., 2002), gluten sensitivity (Goldstein and Underhill, 2001) and wheat allergies (Poole et al., 2006). Although the overall percentage of individuals with confirmed cases of celiac disease is only approximately $1 \%$ of the US population (Weiser and Koehler, 2008), sales of wheat-free foods has had an extensive impact. Bogue and Sorenson (2008) disclosed that gluten-free food sales were approximately $\$ 700$ million in 2006 and would exceed $\$ 5$ billion by 2015 .

Several different flours have been used to produce wheat free foods including crops such as: corn (Sánchez et al., 1996), soybeans (Ranhotra et al., 1975) rice (Ylimaki et al., 1991) and sorghum (Kasarda, 2001).

\footnotetext{
* Corresponding author. Tel.: +1 785776 2703; fax: +1 7855375534 .

E-mail address: tom.herald@ars.usda.gov (T.J. Herald).

1 Names are necessary to report factually on available data; however, the U.S. Department of Agriculture neither guarantees nor warrants the standard of the product, and use of the name by the U.S. Department of Agriculture implies no approval of the product to the exclusion of others that may also be suitable.
}

Even though sorghum is the 5th largest crop produced worldwide and has been shown to be safe for people with celiac disease (Ciacci et al., 2007) the literature is relatively scarce compared to that of corn and rice in exploring sorghum for production of foods for Western markets. Research has shown, however, that sorghum may be used to produce a number of different food products including breads (Schober et al., 2005, 2007), tortilla chips (Rooney and Waniska, 2000), tortillas (Fernholz, 2008), cookies (Morad et al., 1984), flat breads (Badi et al., 1990), and noodles (Kunetz et al., 1997; Miche et al., 1977; Suhendro et al., 2000).

Chinese egg noodles have become one of the fastest growing sectors in the world with a compound annual growth rate reaching $4 \%$ globally (Benkouider, 2003). Thus the production of high quality wheat-free Chinese style noodles would be desirable for the wheatfree food markets. Previous research has shown that sorghum may be used to produce noodles (Kunetz et al., 1997; Miche et al., 1977; Suhendro et al., 2000). Research has shown that a key component governing the end-use quality of sorghum based foods is grain hardness (Fernholz, 2008; Frederick, 2009; Schober et al., 2005). Kernel properties including hardness and sizes impact both the particle size of the final flour as well as starch damage of the flour. These flour attributes in turn play a large role in final product quality. Thus the goal of this study was to evaluate the impact of 
grain properties on the quality of sorghum based Chinese egg noodles.

\section{Experimental}

\subsection{Grain sorghum samples and flour preparation}

Four non-tannin hybrids, two white (Orbit, hybrid No. 1 and Fontanelle-525, hybrid No. 2) and two red (ATX3197 $\times$ RTX7078, hybrid No. 3 and ATX2752 $\times$ RTX2783, hybrid No. 4) grown in Nebraska during 2007 were selected for use in this study. The hybrids were decorticated with a tangential abrasive dehulling device (TADD) until $20 \%$ of the initial weight was removed, then further processed with a Bliss Hammer mill (Venebles Machine Works, Saskatoon, Canada) according to Reichert et al. (1982) and Oomah et al. (1981). The commercial white sorghum flour (Sample No. 5) was obtained as a point of reference for comparing flour characterization and final product quality to the hybrids. The milling profile for the commercial sorghum flour was not provided by the commercial company but the proximate analysis, particle size, and starch pasting properties of commercial sorghum flour were evaluated. To provide a bench mark for noodle quality, wheat flour (Sample No. 6) provided by the Hard Winter Wheat Quality Laboratory (USDA-ARS Manhattan KS) from crop year 2009 was used to compare with final sorghum quality.

\subsection{Methods}

\subsubsection{Kernel characterization}

Physical properties of the sorghum kernels were characterized with the single kernel characterization system (SKCS 4100 Perten Instruments, Huddinge, Sweden) according to Bean et al. (2006).

\subsubsection{Flour analysis}

Proximate analysis on the flour was measured according to the following standard methods: protein (AACC, 2000), ash (AACC, 2000), moisture (AOAC, 2005), fat (AOAC, 2005). Crude fiber was measured according to AOCS Approved Procedure Ba 6a-05 (AOCS, 2006).

Flour particle size distribution was determined with an LS 13320 single wavelength laser diffraction particle size analyzer using the Tornado dry powder system (Beckman-Coulter, Inc., Miami, FL). Amylose and amylopectin content of the starch was determined by the method of Gibson et al. (1995) using a Megazyme amylose/amylopectin assay kit (K-AMYL 04/06, Megazyme International Ireland Ltd., Co. Wicklow, Ireland). The total starch content of the four sorghum flours was determined by Megazyme Total Starch Assay kit, K-TSTA 05/06 (Megazyme International Ireland Ltd., Co. Wicklow, Ireland) which is based on the amyloglucosidase/ $\alpha$-amylase method (AOAC Method No. 996.11). Since sorghum starch may have high levels of resistant starch, a pretreatment with dimethyl sulphoxide (DMSO) was performed. Starch damage was measured by the method of Gibson et al. (1993) (starch damage assay kit from Megazyme).

\subsubsection{Starch isolation}

High-intensity ultrasound (sonication) was used to purify starch from sorghum flour following the procedure of Park et al. (2006). The isolated starch was dried in Labconco Freezone 6 Freeze Dryer (Labconco Corporation, Kansas City, MO).

\subsubsection{Starch particle size distribution}

Starch particle size distribution was determined using an $\mathrm{LS}^{\mathrm{TM}}$ 13320 Laser Diffraction Particle Size Analyzer (Beckman-Coulter,
Inc., Miami, FL) following Approved Method 55-40 (AACC, 2000) in a universal liquid module with an integrated sonicator.

\subsubsection{Starch pasting properties}

Pasting properties of sorghum starch from the four sorghum hybrids were assessed using the rapid visco analyzer (RVA Model 4, Newport Scientific, Australia) method of Lee et al. (2002). The pasting curve is a result of the starch slurry being subjected to a specified thermal profile. In the RVA, the short temperature profile (13 min) was used and the mixture was stirred at $960 \mathrm{rpm}$ for $10 \mathrm{~s}$, and then at $160 \mathrm{rpm}$ for the remainder of the test. The temperature of the test initiated at $50^{\circ} \mathrm{C}$ held for $1 \mathrm{~min}$ and ramp to $95^{\circ} \mathrm{C}$ over $3 \mathrm{~min}$ and $45 \mathrm{~s}$ where the sample was held for $2 \mathrm{~min}$ and $30 \mathrm{~s}$, the temperature was then decreased back down to $50{ }^{\circ} \mathrm{C}$ over $3 \mathrm{~min}$ and $45 \mathrm{~s}$ and was held again for $2 \mathrm{~min}$.

\subsubsection{Preparation of sorghum noodles}

Noodles were made using the modified formulation from Khouryieh et al. (2006): $100 \mathrm{~g}$ sorghum flour, $1.5 \mathrm{~g}$ salt, $8.0 \mathrm{~g}$ dried egg whites, $7.0 \mathrm{~g}$ corn starch, $5.0 \mathrm{~g}$ dried whole eggs, and $2.5 \mathrm{~g}$ xanthan gum. Dry ingredients were added in a Hobart mixer (N50619 mixer, Hobart Food Equipment, North Hobart, Australia) and mixed for $1 \mathrm{~min}$ at low speed followed by $1 \mathrm{~min}$ at high speed. Water (57 g) (based on previous experiment) was added to give uniform, smooth, non-sticky noodle dough. The dough was kneaded by hand for $1 \mathrm{~min}$ and then folded and sheeted through a noodle machine (VillaWare classic Italian Kichenware, Cleveland, $\mathrm{OH}$ ) with the gap set at $4 \mathrm{~mm}$.

The same noodle formulation was used with the commercial sorghum flour but at two different water levels ( $57 \mathrm{~g}$, Sample No. *5 and $75 \mathrm{~g}$, Sample No. ${ }^{* *}$ ). The resultant dough from the $57 \mathrm{~g}$ water level was not as smooth as that observed with the sorghum hybrids used in this study. Thus, an additional dough treatment that used $75 \mathrm{~g}$ water in the formulation was added to the experimental design to closer mimic the physical smooth dough texture and appearance observed with the four sorghum hybrids.

\subsubsection{Evaluation of sorghum noodles}

Optimum cooking time ( $2.5 \mathrm{~min})$ for each noodle sample was determined according to AACC Method 66-50 (AACC, 2000). Approximately $25 \mathrm{~g}$ of noodles were cooked in $300 \mathrm{~mL}$ of distilled water in a $500-\mathrm{mL}$ beaker until the central opaque core in the noodle strand disappeared. Tensile strength of noodles was tested using a TA-XT plus texture analyzer (Texture Technologies Corp., Scarsdale, NY). The TA-XT Plus settings were as follows: pre-test speed of $1.0 \mathrm{~mm} / \mathrm{s}$, test speed of $3.0 \mathrm{~mm} / \mathrm{s}$, post-test speed of $10.0 \mathrm{~mm} / \mathrm{s}$, distance of $100 \mathrm{~mm}$, and trigger force of $5 \mathrm{~g}$. Noodles were tested individually by placing one end into the lower rig arm slot, winding the loosened arm, and tightening the arm. The same procedure was performed on the other noodle end to the upper arm. The distance between the two arms was set as $15 \mathrm{~mm}$. Noodle firmness was tested according to Approved Method 66-50 (AACC, 2000). Water uptake (\%) and cooking loss (\%) during cooking were determined by Approved Method 66-50 (AACC, 2000).

\subsection{Statistical analysis}

Two replications of each test were treated as blocks in a randomized block design. Three subsamples were evaluated for each replicate. All data were analyzed using SAS version 9.1 (SAS, Institute Inc., 2003). Least squares means with Tukey-Kramer groupings were used to differentiate the significant differences among the treatments and treatment means. A level of significance was observed at $\alpha=0.05$. Pearson correlation coefficients were 
Table 1

Comparison of grain physical properties and flour composition of sorghum samples.

\begin{tabular}{|c|c|c|c|c|c|c|c|c|c|c|c|c|c|c|}
\hline $\begin{array}{l}\text { Sample } \\
\text { No. }\end{array}$ & Hybrid names & $\begin{array}{l}\text { Pericarp } \\
\text { color }\end{array}$ & $\begin{array}{l}\text { Single } \\
\text { kernel } \\
\text { hardness }\end{array}$ & $\begin{array}{l}\text { Kernel } \\
\text { weight } \\
\text { (mg) }\end{array}$ & $\begin{array}{l}\text { Kernel } \\
\text { diameter } \\
(\mathrm{mm})\end{array}$ & $\begin{array}{l}\text { Abrasive } \\
\text { hardness } \\
\text { index }\end{array}$ & $\begin{array}{l}\text { Protein } \\
(\% \mathrm{~d} b)\end{array}$ & $\begin{array}{l}\text { Ash } \\
(\% \mathrm{~d} b)\end{array}$ & $\begin{array}{l}\text { Flour } \\
\text { moisture } \\
\text { content (\%) }\end{array}$ & $\begin{array}{l}\text { Crude } \\
\text { fat } \\
(\% \mathrm{~d} b)\end{array}$ & $\begin{array}{l}\text { Crude } \\
\text { fiber } \\
(\% \mathrm{~d} b)\end{array}$ & $\begin{array}{l}\text { Total } \\
\text { starch } \\
(\% \mathrm{~d} b)\end{array}$ & $\begin{array}{l}\text { Starch } \\
\text { damage } \\
(\%)\end{array}$ & $\begin{array}{l}\text { Amylose } \\
(\% \mathrm{~d} b)\end{array}$ \\
\hline 1 & Orbit & White & $98.35^{\mathrm{a}}$ & $30.82^{\mathrm{a}}$ & $2.55^{\mathrm{a}}$ & $14.16^{\mathrm{a}}$ & $10.65^{\mathrm{b}}$ & $1.31^{\mathrm{c}}$ & $14.77^{\mathrm{a}}$ & $3.85^{\mathrm{a}}$ & $1.61^{\mathrm{a}}$ & $68.85^{\mathrm{b}}$ & $3.29^{\mathrm{b}}$ & $27.93^{\mathrm{a}}$ \\
\hline 2 & Fontanelle-525 & White & $78.07^{\mathrm{b}}$ & $23.84^{\mathrm{c}}$ & $2.13^{\mathrm{bc}}$ & $11.96^{\mathrm{ab}}$ & $9.64^{\mathrm{d}}$ & $1.25^{\mathrm{d}}$ & $15.42^{\mathrm{a}}$ & $3.33^{\mathrm{b}}$ & $1.50^{\mathrm{b}}$ & $78.61^{a}$ & $2.58^{\mathrm{c}}$ & $22.06^{\mathrm{c}}$ \\
\hline 3 & ATX3197 $\times$ RTX7078 & Red & $74.98^{\mathrm{b}}$ & $27.31^{\mathrm{b}}$ & $2.17^{\mathrm{b}}$ & $10.26^{\mathrm{b}}$ & $10.04^{\mathrm{c}}$ & $1.40^{\mathrm{b}}$ & $12.60^{\mathrm{b}}$ & $3.72^{\mathrm{a}}$ & $1.64^{\mathrm{a}}$ & $75.30^{\mathrm{a}}$ & $2.81^{\mathrm{c}}$ & $27.51^{\mathrm{a}}$ \\
\hline 4 & ATX2752 × RTX2783 & Red & $96.32^{\mathrm{a}}$ & $24.76^{\mathrm{c}}$ & $1.93^{\mathrm{c}}$ & $13.58^{\mathrm{ab}}$ & $8.96^{\mathrm{e}}$ & $1.41^{\mathrm{b}}$ & $12.78^{\mathrm{b}}$ & $3.64^{\mathrm{a}}$ & $1.69^{\mathrm{a}}$ & $78.63^{\mathrm{a}}$ & $2.78^{\mathrm{c}}$ & $28.46^{\mathrm{a}}$ \\
\hline 5 & $\begin{array}{l}\text { Commercial } \\
\text { sorghum }\end{array}$ & & & & & & $11.30^{\mathrm{a}}$ & $1.59^{\mathrm{a}}$ & $9.20^{c}$ & $2.87^{c}$ & $1.30^{\mathrm{c}}$ & $68.59^{\mathrm{b}}$ & $6.14^{\mathrm{a}}$ & $26.90^{\mathrm{b}}$ \\
\hline 6 & Wheat & & & & & & 12.30 & 0.36 & 12.56 & 0.77 & 0.03 & 70.61 & 6.89 & 31.50 \\
\hline
\end{tabular}

Means in the same column followed by different superscript letters indicate significant differences $(P \leq 0.05)$.

calculated to determine the relationship between grain properties and noodle qualities.

\section{Results and discussion}

\subsection{Kernel properties}

The average hardness indexes of sorghum kernels ranged from 74.98 to 98.35 (Table 1). Hybrids No. 1 and No. 4 exhibited significantly higher kernel hardness than the other two hybrids. Hybrid No.1 showed a significantly higher kernel weight and kernel diameter among the hybrids.

Grain hardness was categorized into low, medium and high based on the work of Bean et al. (2006). Hybrids No. 2 and No. 3 were categorized in the intermediate single kernel hardness range, whereas No. 1 and No. 4 were considered to be in the high single kernel hardness range.

An abrasive hardness index (AHI) was used to calculate the amount of kernel removed over time. The SKCS and AHI are only loosely correlated (Bean et al., 2006) and provide different measures of kernel strength or hardness. The average abrasive hardness indexes of sorghum kernels ranged from 10.26 to 14.16 (Table 1). These values correspond to a 'medium' AHI based on results described by Bean et al. (2006). Many other factors such as kernel shape, kernel size, and pericarp thickness may affect abrasive hardness index (Kirleis and Crosby, 1982).

\subsection{Proximate analysis on sorghum flour}

The commercial sorghum (No. 5) exhibited significantly higher protein content $(\% \mathrm{~d} b)$ and ash content but significantly lower flour moisture, crude fat and crude fiber compared to the sorghum hybrids (Table 1). Among the sorghum hybrids there was no particular trend observed for the proximate analyses data. Hybrid No. 1 exhibited significantly higher protein content. No. 2 exhibited significantly lower in ash, crude fat and fiber compared to the other three hybrids. The red sorghum hybrids were significantly higher in ash content compared to the white sorghum hybrids. These flour protein and ash values were in agreement with those reported by Schober et al. (2005) and Fernholz (2008).

Hybrid No. 1 and the commercial sorghum (No. 5) were significantly lower in total starch compared to the other three hybrids (Table 1). The total sorghum starch results were similar to those of Buffo et al. (1998) and Fernholz (2008) that reported starch content values between 66 and $73 \%(\% \mathrm{~d} b)$. The sorghum hybrids were significantly lower in starch damage (approximately 50\%) compared to the commercial sorghum (No. 5). The difference between the commercial sorghum and sorghum hybrids may be due to the milling method used (Frederick, 2009). Hybrid No. 1 exhibited a significantly higher starch damage compared to the other hybrids. Hybrid No. 1 did exhibit a harder kernel trait and larger kernel size which is often associated with high starch damage (Table 5) because of the additional energy input required to mill the grain (Martin et al., 2007). Fernholz (2008) used an analogous milling method and reported similar starch damage values (2.7-3.0\%).

Hybrid No. 2 exhibited a significantly lower amylose content compared to the other hybrids (Table 1 ). The commercial sorghum (No. 5) exhibited amylose content between the No. 2 and No. 3. These results are similar to those reported by Fernholz (2008) which ranged from 20.2 to $27.3 \%(\mathrm{~d} b)$.

\subsection{Starch and flour particle size distribution}

The starch particle size distribution was represented according to diameter vs. volume \% using two different binning regimes. In one regime, the A-type ( $>15 \mu \mathrm{m})$, B-type $(5-15 \mu \mathrm{m})$, and C-type $(<5 \mu \mathrm{m})$ allowed a comparison through a commonly used method (Wilson et al., 2006, 2008). In the second regime, the binning of the particles was done in six groups: $>30 \mu \mathrm{m}, 20-30 \mu \mathrm{m}, 10-20 \mu \mathrm{m}$, $5-10 \mu \mathrm{m}, 2-5 \mu \mathrm{m}$, and $<2 \mu \mathrm{m}$. This regime was developed for this work to determine whether binning in smaller groups would be useful for starch size distribution studies and to better relate starch size distributions to noodle properties. Hybrid No. 1 showed a significantly higher volume \% in the A-type particles and lower volume \% in the B-type and C-type particles in the starch compared with other three sorghum hybrids and commercial sorghum (Table 2). Starch from commercial sorghum showed a significantly

Table 2

Comparison of starch particle size distribution (volume \%) of four sorghum hybrids, commercial sorghum and wheat flour samples.

\begin{tabular}{|c|c|c|c|c|c|c|c|c|c|}
\hline \multirow[t]{2}{*}{ Sample No. } & \multicolumn{9}{|c|}{ Particle size distribution (volume \%) } \\
\hline & $<2 \mu \mathrm{m}$ & $2-5 \mu \mathrm{m}$ & $5-10 \mu \mathrm{m}$ & $10-20 \mu \mathrm{m}$ & $20-30 \mu \mathrm{m}$ & $>30 \mu \mathrm{m}$ & $\begin{array}{l}\text { A-type } \\
>15 \mu \mathrm{m}\end{array}$ & $\begin{array}{l}\text { B-type } \\
5-15 \mu \mathrm{m}\end{array}$ & $\begin{array}{l}\text { C-type } \\
<5 \mu \mathrm{m}\end{array}$ \\
\hline 1 & $2.84^{\mathrm{c}}$ & $4.36^{\mathrm{b}}$ & $12.04^{\mathrm{d}}$ & $38.04^{\mathrm{d}}$ & $28.60^{\mathrm{a}}$ & $14.13^{\mathrm{a}}$ & $64.20^{\mathrm{a}}$ & $28.60^{\mathrm{d}}$ & $7.20^{\mathrm{C}}$ \\
\hline 2 & $4.11^{\mathrm{b}}$ & $4.62^{\mathrm{b}}$ & $14.66^{\mathrm{c}}$ & $42.17^{\mathrm{c}}$ & $26.08^{\mathrm{b}}$ & $8.36^{\mathrm{b}}$ & $56.56^{\mathrm{b}}$ & $34.71^{\mathrm{c}}$ & $8.73^{\mathrm{b}}$ \\
\hline 3 & $4.48^{\mathrm{b}}$ & $4.32^{\mathrm{b}}$ & $15.35^{\mathrm{bc}}$ & $42.44^{\mathrm{bc}}$ & $24.26^{\mathrm{b}}$ & $9.16^{\mathrm{b}}$ & $55.08^{\mathrm{bc}}$ & $36.12^{\mathrm{bc}}$ & $8.80^{\mathrm{b}}$ \\
\hline 4 & $4.55^{\mathrm{b}}$ & $4.52^{\mathrm{b}}$ & $17.07^{\mathrm{b}}$ & $44.72^{\mathrm{b}}$ & $24.31^{\mathrm{b}}$ & $4.83^{\mathrm{c}}$ & $51.70^{c}$ & $39.22^{\mathrm{b}}$ & $9.07^{\mathrm{b}}$ \\
\hline 5 & $5.65^{\mathrm{a}}$ & $8.57^{\mathrm{a}}$ & $20.95^{\mathrm{a}}$ & $47.80^{\mathrm{a}}$ & $11.09^{c}$ & $5.93^{\mathrm{c}}$ & $38.22^{\mathrm{d}}$ & $47.55^{\mathrm{a}}$ & $14.22^{\mathrm{a}}$ \\
\hline 6 & 4.15 & 13.92 & 16.25 & 24.57 & 22.65 & 18.46 & 54.55 & 27.39 & 18.06 \\
\hline
\end{tabular}

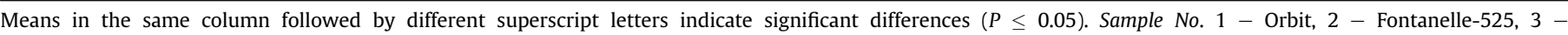
ATX3197 $\times$ RTX7078, 4 - ATX2752 × RTX2783, 5 - Commercial sorghum, 6 - Wheat. 
lower volume \% in the A-type particles and higher volume \% in the B-type and C-type particles compared with the four hybrids. When starch populations are segmented into six groups, Hybrid No. 1 showed a significantly greater volume \% in the largest particle group of $>30 \mu \mathrm{m}$, while No. 4 and the commercial sorghum (No. 5) showed lower volume \% in that group. The $20-30 \mu \mathrm{m}$ size group showed hybrid No.1 had higher volume \% and the commercial sorghum (No. 5) had lower volume \% compared with other three hybrids. In the $10-20 \mu \mathrm{m}, 5-10 \mu \mathrm{m}, 2-5 \mu \mathrm{m}$ and $<2 \mu \mathrm{m}$ size groups, the commercial sorghum (No. 5) was significantly higher in volume \%, while No. 1 was lower in volume \%, hybrids No. 2, 3 and 4 showed no significant difference in volume $\%$.

The distribution of flour particle size at 5 volume percents is shown in Table 3. Significant differences among flour type and particle size were found at each of volume percent. Hybrid No. 1 exhibited a significantly higher particle size at volume \% 10, 25 and 50. The average flour particle diameters ranged from $38.78 \mu \mathrm{m}$ to $177.00 \mu \mathrm{m}$ at 50 volume percent. The commercial sorghum (No. 5) exhibited a significantly smaller average flour particle at all volume percents measured. Fernholz (2008) reported average flour particle diameter of four sorghum hybrids ranging from 154.4 to $191.8 \mu \mathrm{m}$ at 50 volume percents.

\subsection{Starch pasting properties}

Pasting profiles of sorghum starch provided a unique functional fingerprint for each hybrid that may represent structural and molecular structure. The commercial sorghum (No. 5) exhibited the highest peak viscosity (Fig. 1), whereas hybrid No. 3 exhibited the lowest peak viscosity. The data reported is similar to that of Beta and Corke (2001) with average peak average viscosity data for 95 sorghum hybrids grown in Zimbabwe was 324 RVU. Trough viscosity, an indication of holding strength, ranged from 75.58 RVU (No. 4) to 116.25 RVU (No. 5). Breakdown viscosity ranged from 285.54 RVU (No. 3) to 461.29 RVU (No. 5). Setback viscosity ranged from 147.7 RVU (No. 4) to $209.00 \mathrm{RVU}$ (No. 1). Setback is a process that occurs during cooling in which the starch molecules started to reorder and subsequently form a gel structure. A lower setback values is indicative of slower rates of starch retrogradation (Varavinit et al., 2003). No relationship between sorghum starch amylose content and setback viscosity was found in this research. Peak time is the time required to achieve peak viscosity. Pasting temperature ranged from $69.73{ }^{\circ} \mathrm{C}$ (No. 5) to $75.18{ }^{\circ} \mathrm{C}$ (No. 4). According to the peak viscosity (456-810 RVU) and time required to develop peak viscosity (6.42-7.25 min) reported by Suhendro et al. (2000), the four hybrids had lower peak viscosity and shorter peak development time. The pasting temperature is defined by the initial increase in viscosity and is higher than the gelatinization temperature, meaning the starch particles are gelatinized before the viscosity begins to increase (Liang and King, 2003). In this study lower pasting temperature was found to be associated with faster

Table 3

Comparison of flour particle size distribution of four sorghum hybrids, commercial sorghum and wheat flour samples.

\begin{tabular}{lcccccr}
\hline Volume \% & \multicolumn{6}{l}{ Particle diameter $(<\mu \mathrm{m})$} \\
\cline { 2 - 7 } & 1 & 2 & 3 & 4 & \multicolumn{1}{l}{5} & \multicolumn{1}{l}{6} \\
\hline 10 & $34.10^{\mathrm{a}}$ & $25.65^{\mathrm{c}}$ & $28.90^{\mathrm{b}}$ & $27.45^{\mathrm{bc}}$ & $11.52^{\mathrm{e}}$ & 17.04 \\
25 & $92.95^{\mathrm{a}}$ & $78.20^{\mathrm{c}}$ & $91.35^{\mathrm{ab}}$ & $84.15^{\mathrm{bc}}$ & $17.31^{\mathrm{e}}$ & 33.51 \\
50 & $173.50^{\mathrm{ab}}$ & $148.00^{\mathrm{c}}$ & $177.00^{\mathrm{a}}$ & $167.50^{\mathrm{b}}$ & $38.78^{\mathrm{e}}$ & 61.61 \\
75 & $256.50^{\mathrm{b}}$ & $238.00^{\mathrm{c}}$ & $271.00^{\mathrm{a}}$ & $271.00^{\mathrm{a}}$ & $80.83^{\mathrm{e}}$ & 91.39 \\
90 & $326.50^{\mathrm{b}}$ & $314.00^{\mathrm{b}}$ & $349.50^{\mathrm{a}}$ & $351.50^{\mathrm{a}}$ & $117.21^{\mathrm{c}}$ & 117.20 \\
\hline
\end{tabular}

Means in the same row followed by different superscript letters indicate significant differences $(P \leq 0.05)$. Sample No. 1 - Orbit, 2 - Fontanelle-525, 3 ATX3197 $\times$ RTX7078, 4 - ATX2752 $\times$ RTX2783, 5 - Commercial sorghum, 6 Wheat.

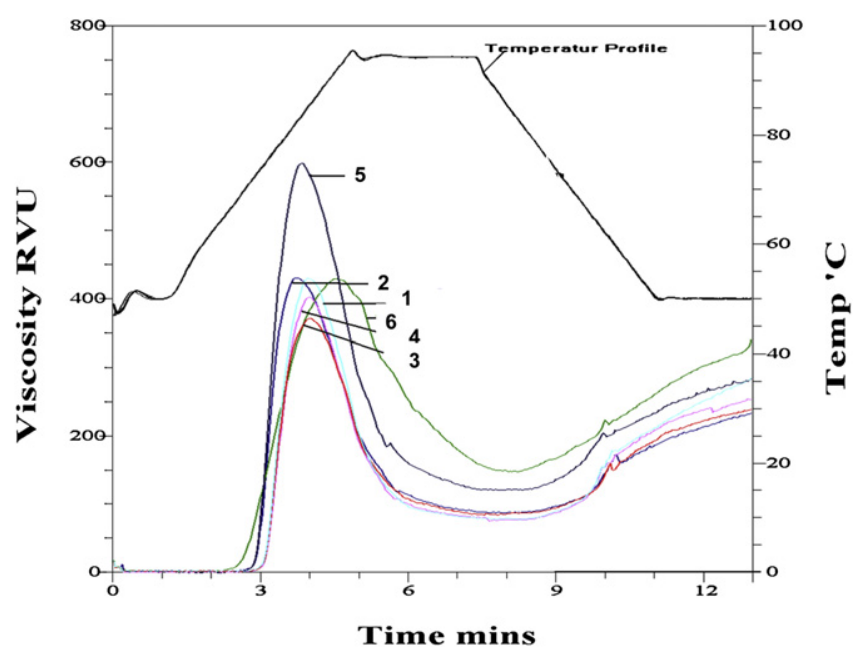

Fig. 1. Representative image depicting the starch pasting properties of selected four sorghum hybrids, commercial sorghum and wheat samples. Sample No. 1 - Orbit, 2 Fontanelle-525, 3 - ATX3197 $\times$ RTX7078, 4 - ATX2752 $\times$ RTX2783, 5 - Commercial sorghum, 6 - Wheat.

particle swelling and higher peak viscosity which agreed with Hernandez (2009).

Starch size distributions showed some significant correlations to RVA pasting properties (Table 5 ). The $2-5 \mu \mathrm{m}$ size group was positively correlated to breakdown viscosity. The C-type particles and $2-5 \mu \mathrm{m}$ group showed a positive correlation to peak viscosity and trough viscosity, and $20-30 \mu \mathrm{m}$ group resulted in a negative correlation. Lower pasting viscosity was as a result of A-type granules, which was in contrast to wheat starch study reported by Geera et al. (2006). B-type and C-type starch granules resulted in higher pasting viscosity, breakdown viscosity and trough viscosity (Table 5). Thus, smaller starch particle size was observed to have higher viscosity, which was contrary to wheat starch literature (Shinde et al., 2003; Wilson et al., 2008; Wong and Lelievre, 1981, 1982). These results could result from physical and/or chemical variations between wheat and sorghum starches.

\subsection{Cooked noodle qualities}

Noodles from hybrids No. 1, 3 and 4 exhibited higher firmness compared to No. 2 (Table 4). The commercial sorghum noodle (No. ${ }^{*} 5$ ) formulated at the lower water level resulted in cooked noodles with firmest texture, although the commercial sorghum noodle (No. $\left.{ }^{* *} 5\right)$ with higher water level treatment was significantly higher

Table 4

Comparison of sorghum noodle texture and cooking quality of four sorghum hybrids, commercial sorghum and wheat samples.

\begin{tabular}{lllll}
\hline $\begin{array}{l}\text { Sample } \\
\text { No. }\end{array}$ & \multicolumn{4}{l}{ Cooked noodles } \\
\cline { 2 - 5 } & $\begin{array}{l}\text { Firmness (g- } \\
\text { force) }\end{array}$ & $\begin{array}{l}\text { Tensile strength (g- } \\
\text { force) }\end{array}$ & $\begin{array}{l}\text { Cooking loss } \\
(\%)\end{array}$ & $\begin{array}{l}\text { Water uptake } \\
(\%)\end{array}$ \\
\hline 1 & $306.01^{\mathrm{cd}}$ & $31.00^{\mathrm{c}}$ & $4.88^{\mathrm{c}}$ & $81.56^{\mathrm{c}}$ \\
2 & $267.16^{\mathrm{d}}$ & $32.34^{\mathrm{c}}$ & $4.01^{\mathrm{e}}$ & $77.14^{\mathrm{d}}$ \\
3 & $324.84^{\mathrm{c}}$ & $32.53^{\mathrm{c}}$ & $5.53^{\mathrm{b}}$ & $98.58^{\mathrm{b}}$ \\
4 & $320.09^{\mathrm{c}}$ & $37.34^{\mathrm{b}}$ & $4.42^{\mathrm{d}}$ & $79.12^{\mathrm{d}}$ \\
$5^{\mathrm{f}}$ & $486.02^{\mathrm{a}}$ & $48.43^{\mathrm{a}}$ & $6.08^{\mathrm{a}}$ & $113.92^{\mathrm{a}}$ \\
$5^{\mathrm{g}}$ & $407.24^{\mathrm{b}}$ & $35.62^{\mathrm{b}}$ & $4.86^{\mathrm{c}}$ & $105.8^{\mathrm{b}}$ \\
6 & 240.79 & 31.55 & 5.95 & 163.70 \\
\hline
\end{tabular}

Means in the same column followed by different superscript letters indicate significant differences $(P \leq 0.05)$. Sample No. 1 - Orbit, 2 - Fontanelle-525, 3 ATX3197 $\times$ RTX7078, $4-$ ATX2752 $\times$ RTX2783, $5-$ Commercial sorghum, $6-$ Wheat.

f Noodles formulated with commercial sorghum flour with $57 \mathrm{~g}$ water.

$\mathrm{g}$ Noodles formulated with commercial sorghum flour with $75 \mathrm{~g}$ water. 
Table 5

Pearson correlation coefficients of starch pasting properties and noodle qualities as a function of starch particle size and flour properties respectively of five sorghums. ${ }^{\text {a }}$

\begin{tabular}{|c|c|c|c|c|c|c|c|c|}
\hline & \multicolumn{3}{|c|}{ Kernel properties } & \multicolumn{3}{|c|}{ Starch pasting properties } & \multicolumn{2}{|l|}{ Noodle qualities } \\
\hline & Kernel size & Kernel weight & Peak viscosity & Trough & Breakdown & Firmness & Tensile strength & Water uptake \% \\
\hline \multicolumn{9}{|l|}{ Starch particle size } \\
\hline A-Type & & & -0.80 & $-0.88^{*}$ & -0.74 & $-0.87^{*}$ & $-0.96^{* *}$ & - \\
\hline B-Type & & & 0.74 & $0.84^{*}$ & 0.69 & $0.84^{*}$ & $0.94^{*}$ & - \\
\hline C-Type & & & $0.90^{*}$ & $0.96^{* *}$ & $0.85^{*}$ & $0.93^{*}$ & $0.97^{* *}$ & - \\
\hline $2-5 \mu \mathrm{m}$ & & & $0.98^{* *}$ & $0.96^{* *}$ & $0.94^{*}$ & $0.95^{* *}$ & $0.95^{* *}$ & - \\
\hline $5-10 \mu \mathrm{m}$ & & & - & - & - & - & $0.95^{* *}$ & - \\
\hline $10-20 \mu \mathrm{m}$ & & & - & - & - & - & $0.89^{*}$ & - \\
\hline $20-30 \mu \mathrm{m}$ & & & $-0.89 *$ & $-0.97^{* *}$ & - & $-0.96^{* *}$ & $-0.97^{* *}$ & - \\
\hline$>30 \mu \mathrm{m}$ & & & - & - & - & - & - & $-0.87^{*}$ \\
\hline Flour particle size & - & 0.71 & & & & $-0.90^{*}$ & $-0.93^{*}$ & -0.76 \\
\hline \multicolumn{9}{|c|}{ Starch pasting properties } \\
\hline Peak viscosity & & & 1.00 & & & $0.89^{*}$ & $0.90^{*}$ & - \\
\hline Trough & & & & 1.00 & & $0.94^{*}$ & $0.88^{*}$ & $0.93^{*}$ \\
\hline Breakdown & & & & & 1.00 & - & $0.89 *$ & - \\
\hline Starch damage & $0.83^{*}$ & $0.96^{*}$ & & & & $0.97^{* *}$ & $0.90^{*}$ & $0.84^{*}$ \\
\hline Flour moisture & & & & & & $-0.95^{* *}$ & $-0.91^{*}$ & $-0.90^{*}$ \\
\hline
\end{tabular}

*, **, Significant at $P<0.05, P<0.01$.

- Means not significantly different.

${ }^{\text {a }}$ Four sorghum hybrids No. 1, 2, 3, 4 and one commercial sorghum sample No. ${ }^{*} 5$.

than the sorghum hybrid flour noodle treatments. There were no significant differences for tensile strength among four sorghum hybrids. The tensile strength of the noodles formulated with the commercial sorghum (No. ${ }^{*} 5$ ), $57 \mathrm{~g}$ water level, was significantly higher than the other noodle treatments. The difference noted between the tensile strength of the noodles formulated with No. ${ }^{*} 5$ vs. No. ${ }^{* *} 5$ may be the result of plasticizing effect of the water (Bellido and Hatcher, 2009). Flour moisture content was negatively correlated with firmness $(r=-0.95, P<0.01)$ and tensile strength $(r=-0.91, P<0.05)$ (Table 5$)$. The small size starch particles of $2-5 \mu \mathrm{m}$ was positively correlated with cooked noodle firmness $(r=0.95, P<0.01)$. The A-type starch particles and $20-30 \mu \mathrm{m}$ starch size group were negatively correlated with tensile strength. C-type and B-type starch granules resulted in firmer noodles which agreed with Soh et al. (2006), whereas the A-type starch granules resulted in softer noodles. Higher starch pasting viscosity was found to be related with firmer noodles. The reason of this finding was because smaller particle size resulted in firmer noodles (Hatcher et al., 2002) and higher pasting viscosity (Sahai et al., 2001). Maximum firmness and tensile strength were found in fine flour particle size and high starch damage flour that came from harder kernels. Hatcher et al. (2002) reported that the white salted noodles formulated with wheat flours with fine particle size between 85 and $110 \mu \mathrm{m}$ exhibited better textural attributes than noodles formulated with coarse particle sizes, the fine flour noodles exhibited firmer texture with significantly higher maximum cutting stress and resistance to compression values than either the intermediate or coarse flour noodles. Flour protein was not found to have any relationship with cooked noodle texture properties. This was not unexpected given that sorghum proteins do not form a functional protein network which contributes to the cooked noodle texture as wheat protein (Suhendro et al., 2000).

Cooking loss is defined as the amount of solids that dissolve in the water during cooking. Thus cooking loss may be an indicator of noodles structural integrity during cooking. Noodles formulated with the commercial sorghum flour, $57 \mathrm{~g}$ water level (No. ${ }^{*} 5$ ), showed a higher cooking loss than the other hybrids (Table 4). No relationship was found between cooking loss and starch properties in this research. This agrees with the research of Beta and Corke (2001) that reported sorghum noodle cooking loss was low and not significantly correlated with starch properties.

Water uptake is an indication of the quantity of water absorbed by the noodles during cooking. An inverse relationship $(r=-0.90$,
$P<0.05)$ between moisture content and water uptake was found for the samples used in this study (Table 5). Water uptake of noodles was affected by flour particle size. The commercial sorghum samples No. ${ }^{*} 5$ and No. ${ }^{* *} 5$ exhibited significantly higher water uptake compared to the hybrids. This indicates that water uptake by the noodles increased with decreasing flour particle size and increasing starch damage.

\subsection{Adjusted water absorption}

As anticipated, the high starch damage and small particle size flour required more water than low starch damage and coarse flours. The high starch damage fine commercial sorghum flour required $75 \%$ water absorption to display an equivalent consistency at $57 \%$ based on observation. Torres et al. (1994) found that a smaller sorghum flour particle size distribution exhibited greater water absorption within the dough. Increasing the water content in the commercial sorghum flour formulation from $57 \mathrm{~g}$ to $75 \mathrm{~g}$ resulted in a 20\% decrease in fresh noodle firmness and cooking loss (Table 4). Even the commercial sorghum noodles (No. ${ }^{* *} 5$ ) formulated with $75 \%$ water was significantly higher than the sorghum hybrid flour noodle treatments for firmness and water uptake.

\section{Conclusions}

The understanding the sorghum grain quality attributes are critical in translating to end product use. Sorghum is similar to other grains in that individual hybrids have different grain quality characteristics that may dictate end product quality and application. The sorghum hybrids evaluated under identical processing conditions yielded noodles with significant differences in physical quality. Kernel size and weight are key elements for these differences. Thus, knowing grain quality, flour quality and end use application are necessary in hybrid selection. Through control of starch damage and flour particle size, it is possible to manufacture Chinese noodles with good physical attributes.

\section{Acknowledgments}

The authors wish to thank Mr. Kevin Fay for providing nitrogen combustion analysis and Mrs. Susan Xiao for starch pasting analysis. 


\section{References}

AACC, 2000. Approved Methods of the American Association of Cereal Chemists. Methods 08-01, 46-30, 55-40, 66-50, 76-13, and 76-31, tenth ed. The Association, St Paul, MN.

AOAC, 2005. Official Methods of Analysis of AOAC International. Methods 920.39, 934.01 and 996.11, eighteenth ed.. AOAC International, Gaithersburg, MD.

AOCS, 2006. Approved Procedure Ba 6a-05. ANKOM Technology Method 10.

Badi, S., Pedersen, B., Monowar, L., Eggum, B.O., 1990. The nutritive value of new and traditional sorghum and millet foods from Sudan. Plant Foods for Human Nutrition (Formerly Qualitas Plantarum) 40, 5-19.

Bean, S.R., Chung, O.K., Tuinstra, M.R., Pedersen, J.F., Erpelding, J., 2006. Evaluation of single kernel characterization system (SKCS) for measurement of sorghum grain attributes. Cereal Chemistry 83, 108-113.

Bellido, G.G., Hatcher, D.W., 2009. Stress relaxation behaviour of yellow alkaline noodles: effect of deformation history. Journal of Food Engineering 93, 460-467.

Benkouider, C., 2003. Can Noodles Compete in Europe's Snack Food Market? Available online at: http://www.euromonitor.com/Can_noodles_compete_in_ Europes_snack_food_market.

Beta, T., Corke, H., 2001. Noodle quality as related to sorghum starch properties. Cereal Chemistry 78, 417-420.

Bogue, J., Sorenson, D., 2008. The Marketing of Gluten-free Cereal Products. Gluten-free Cereal Products and Beverages. Elsevier Inc, New York, pp. 393-412.

Buffo, R.A., Weller, C.L., Parkhurst, A.M., 1998. Relationships among grain sorghum quality factors. Cereal Chemistry 75, 100-104.

Ciacci, C., Maiuri, L., Caporaso, N., Bucci, C., Del Giudice, L., Rita Massardo, D. Pontieri, P., Di Fonzo, N., Bean, S.R., Ioerger, B., Londei, M., 2007. Celiac disease: in vitro and in vivo safety and palatability of wheat-free sorghum food products. Clinical Nutrition 26, 799-805.

Cole, S.G., Kagnoff, M.F., 1985. Celiac disease. Annual Review of Nutrition 5, 241-266.

Collin, P., Kaukinen, K., Valimaki, M., Slami, J., 2002. Endocrinological disorders and celiac disease. Endocrine Reviews 23, 464-483.

Fernholz, M.C., 2008. Evaluation of four sorghum hybrids through the development of sorghum flour tortillas. Master thesis. Available on line: http://krex.k-state. edu/dspace/bitstream/2097/729/1/MaryFernholz2008.pdf.

Frederick, E.J., 2009. Effect of sorghum flour composition and particle size on quality of gluten-free bread. Master thesis. Available on line: http://www. agronavigator.cz/UserFiles/File/Agronavigator/Sukova2/irok.pdf.

Geera, B.P., Nelson, J.E., Souza, E., Huber, K.C., 2006. Composition and properties of A- and B-type starch granules of wild-type, partial waxy, and waxy soft wheat. Cereal Chemistry 83, 551-557.

Gibson, T.S., Kaldor, C.J., McCleary, B.V., 1993. Collaborative evaluation of an enzymatic starch damage assay kit and comparison with other methods. Cereal Chemistry 70, 47-51.

Gibson, T.S., McCleary, B.V., Solah, V.A., 1995. Con A revisited a simplified assay to measure amylose in cereal starches. In: Williams, Y.A., Wrigley, C.W. (Eds.) Proc. 45th Australian Cereal Chemistry Conference. RACI: Melbourne, pp. 1621-1665.

Goldstein, N.S., Underhill, J., 2001. Morphologic features suggestive of gluten sensitivity in architecturally normal duodenal biopsy specimens. American Journal of Clinical Pathologists 116, 63-71.

Hatcher, D.W., Anderson, M.J., Desjardins, R.G., Edwards, N.M., Dexter, J.E., 2002. Effects of flour particle size and starch damage on processing and quality of white salted noodles. Cereal Chemistry 79, 64-71.

Hernandez, J.R., 2009. Simultaneous saccharification and fermentation of dry-grind highly digestible grain sorghum lines for ethanol production. Master thesis Available on line: http://repository.tamu.edu/bitstream/handle/1969.1/ETDTAMU-2009-05-771/HERNANDEZ-THESIS.pdf? sequence $=1$.

Kasarda, D.D., 2001. Grains in relation to celiac disease. Cereal Foods World 46, 209-210.

Khouryieh, H., Herald, T., Aramouni, F., 2006. Quality and sensory properties of fresh egg noodles formulated with either total or partial replacement of egg substitutes. Journal of Food Science 71, 433-437.

Kirleis, A.W., Crosby, K.D., 1982. . Sorghum hardness: comparison of methods for its evaluation. In: Rooney, L.W., Murty, D.S. (Eds.), Proceedings of the International Symposium on Sorghum Grain Quality, October 28-31, 1981. International Crops Research Institute for the Semi-Arid Tropics (ICRISAT), Pantancheru, A.P. India, pp. 231-241.

Kunetz, C.F., Almeida-Dominguez, H., McDonough, C.M., Wanika, R.D., Rooney, L.W., 1997. Cooking characteristics and quality of noodles from food sorghum. Cereal Foods World 42, 624.
Lee, W.J., Pedersen, J.F., Shelton, D.R., 2002. Relationship of sorghum kernel size to physiochemical, milling, pasting, and cooking properties. Food Research International 35, 643-649.

Liang, X., King, J.M., 2003. Pasting and crystalline property differences of commercial and isolate rice starch with added amino acids. Journal of Food Science 68, 832-838.

Martin, J.M., Meyer, F.D., Morris, C.F., Giroux, M.J., 2007. Pilot scale milling characteristics of transgenic isolines of a hard wheat over-expressing puroindolines. Crop Science 47, 497-506.

Miche, J.C., Alary, R., Jeanjean, M.F., Abecassis, J., 1977. Potential use of sorghum grains in pasta processing. In: Dendy, D.A.V. (Ed.), Sorghum and Milletes for Human Food. Tropical Products Institute, London, pp. 27-35.

Morad, M.M., Doherty, C.A., Rooney, L.W., 1984. Effect of sorghum variety on baking properties of US conventional bread, Egyptian pita "Balady" bread and cookies. Journal of Food Science 49, 1070-1074.

Oomah, B.D., Reichert, R.D., Youngs, C.G., 1981. A novel, multi-sample, tangential abrasive dehulling device (TADD). Cereal Chemistry 58, 392.

Park, S.H., Bean, S.R., Wilson, J.D., Schober, T.J., 2006. Rapid isolation of sorghum and other cereal starches using sonication. Cereal Chemistry 83, 611-616.

Poole, J.A., Barriga, K., Leung, D.Y.M., Hoffman, M., Eisenbarth, G.S., Rewers, M., Norris, J.M., 2006. Timing of initial exposure to cereal grains and the risk of wheat allergy. Pediatrics 117, 2175-2182.

Ranhotra, G.S., Loewe, R.J., Puyat, L.U., 1975. Preparation and evaluation of soy fortified gluten free bread. Journal of Food Science 40, 62-64.

Reichert, R.D., Youngs, C.G., Oomah, B.D., 1982. Measurement of grain hardness and dehulling quality with a multi-sample, tangential abrasive dehulling device (TADD). In: Rooney, L.W., Murty, D.S. (Eds.), Proceedings of International Symposium Sorghum Grain Quality, 1981. International Crops Research Institute for the Semi-Arid Tropics (ICRISAT), Patancheru, India, p. 186.

Rooney, L.W., Waniska, R.D., 2000. Sorghum food and industrial utilization. In: Smith, C.W., Frederiksen, R.A. (Eds.), Sorghum: Origin, History, Technology, and Production. Wiley, New York, pp. 689-729.

Sahai, D., Buendia, M.O., Jackson, D.S., 2001. Analytical techniques for understanding nixtamalized corn flour: particle size and functionality relationships in a masa flour sample. Cereal Chemistry 78, 14-18.

Sánchez, H.D., Osella, C.A., de la Torre, M.A., 1996. Desarrollo de una fórmula para Pan sin gluten. Información Tecnológica 7, 35-42.

SAS version 9.1, 2003. SAS Institute Inc, Cary, NC.

Schober, T.J., Messerschmidt, M., Bean, S.R., Park, S.H., Arendt, E.K., 2005. Glutenfree bread from sorghum: quality differences among hybrids. Cereal Chemistry 82, 394-404.

Schober, T.J., Bean, S.R., Boyle, D.L., 2007. Gluten-free sorghum bread improved by sourdough fermentation: biochemical, rheological, and microstructural background. Journal of Agricultural and Food Chemistry 55, 5137-5146.

Shinde, S.V., Nelson, J.E., Huber, K.C., 2003. Soft wheat starch pasting behavior in relation to A- and B-type particle content and composition. Cereal Chemistry 80, 91-98.

Soh, H.N., Sissons, M.J., Turner, M.A., 2006. Effect of starch granule size distribution and elevated amylase content on durum dough rheology and spaghetti cooking quality. Cereal Chemistry 83, 513-519.

Suhendro, E.L., Kunetz, C.F., Mcdonough, C.M., Rooney, L.W., Waniska, R.D., 2000 Cooking characteristics and quality of noodles from food sorghum. Cereal Chemistry 77, 96-100.

Torres, P.I., Ramirez-Wong, B., Serna-Saldivar, S.O., Rooney, L.W., 1994. Effect of decorticated sorghum addition on the rheological properties of wheat tortilla dough. Cereal Chemistry 71, 509-512.

Varavinit, S., Shobsngob, S., Warunee, V., 2003. Effect of amylose content on gelatinization, Retrogradation and pasting properties of different cultivars of Thai rice. Starch/Stärke 55, 410-415.

Weiser, H., Koehler, P., 2008. The Biochemical Basis of Celiac Disease, vol. 85. American Association of Cereal Chemist International, Inc, pp. 1-13.

Wilson, J.D., Bechtel, D.B., Todd, T.C., Seib, P.A., 2006. Measurement of wheat starch particle size distribution using image analysis and laser diffraction technology. Cereal Chemistry 83, 259-268.

Wilson, J.D., Bechtel, D.B., Wilson, G.W.T., Seib, P.A., 2008. Bread quality of spelt wheat and its starch. Cereal Chemistry 85, 629-638.

Wong, R.B.K., Lelievre, J., 1981. Viscoelastic behavior of wheat starch pastes. Rheologica Acta 20, 299-307.

Wong, R.B.K., Lelievre, J., 1982. Rheological characteristics of wheat-starch pastes measured under steady shear conditions. Journal of Applied Polymer Science 27, 1433-1440.

Ylimaki, G., Hawrysh, Z.J., Hardin, R.T., Thomson, B.R., 1991. Application of response surface methodology to the development of rice flour yeast breads: sensory evaluation. Journal of Food Science 53, 751-759. 